JPPIPA, Vol. 1 No. 22016
JPPIPA (Jurnal Penelitian Pendidikan IPA)

\title{
PEMBELAJARAN DISCOVERY DISERTAI PENULISAN JURNAL BELAJAR UNTUK MENINGKATKAN KEMAMPUAN KERJA ILMIAH SISWA KELAS VIII.1 SMP NEGERI 1 PROBOLINGGO
}

Oleh:

Nur Hidayati

SMPN 1 Probolinggo

\begin{abstract}
Abstrak
Kemampuan kerja ilmiah penting bagi siswa saat belajar IPA maupun masa depannya, karena melalui serangkaian kerja ilmiah, pengetahuan yang didapat menjadi lebih bermakna yang pada akhirnya siswa memiliki cara berpikir dan beraktivitas sebagai saintis melalui metode ilmiah. Kemampuan kerja ilmiah masih rendah terutama dalam merumuskan masalah dan hipotesis sehingga dibutuhkan pembelajaran yang menekankan kerja ilmiah pada setiap proses pembelajaran. Penelitian ini merupakan Penelitian Tindakan Kelas yang dilaksanakan dengan dua siklus terdiri dari tahap perencanaan, pelaksanaan, observasi, dan refleksi. Subyek penelitian adalah siswa kelas VIII.1 SMPN 1 Probolinggo. Data dalam penelitian ini meliputi data keterlaksanaan pembelajaran, jurnal belajar, dan kemampuan kerja ilmiah. Pengumpulan data dengan metode dokumentasi dan observasi. Hasil penelitian menunjukkan bahwa pembelajaran Discovery disertai penulisan jurnal belajar dapat meningkatkan kemampuan kerja ilmiah kelas VIII.1 SMP Negeri 1 Probolinggo. Keterlaksanaan pembelajaran meningkat $7.75 \%$ dari $90.50 \%$ menjadi $98.25 \%$, terjadi peningkatan kemampuan dalam menulis jurnal belajar, dan kemampuan kerja ilmiah meningkat $23 \%$ dari $73.50 \%$ menjadi $96.50 \%$.
\end{abstract}

Kata Kunci: Pembelajaran Discovery, Jurnal Belajar, Kemampuan Kerja Ilmiah.

\begin{abstract}
The ability of the scientific work is important for students when studying science and the future. Through a series of scientific work, knowledge gained becomes more meaningful in the end the students have a way of thinking and activity as scientists through scientific methods. The ability of the scientific work is low, especially on formulating problems and hypotheses that take learning that emphasizes the scientific work on each lesson. This research is a classroom action research conducted by two cycles consist of planning, implementation, observation, and reflection. Subjects were students of SMPN 1 Probolinggo VIII.1 class. The collection of data by the method of documentation and observation. The data in this study includes data implementation learning, learning journals, and scientific workability. The results of this study indicate that Discovery learning with learning journal writing can improve scientific working class VIII.1 SMP Negeri 1 Probolinggo. Keterlaksanaan learning increases $7.75 \%$ from $90.50 \%$ to $98.25 \%$, an increase in the ability of learning journal writing, and the ability of scientific work increased $23 \%$ from $73.50 \%$ to $96.50 \%$.
\end{abstract}

Keywords: Discovery Learning, Learning Journal, Scientific Work Capability.

C 2016 Universitas Negeri Surabaya

Alamat Korespondensi:

SMP Negeri 1 Probolinggo

p-ISSN: 2527-7537

Probolinggo, Indonesia

e-ISSN: 2549-2209

Email: noeng_bintang71@yahoo.co.id 


\section{PENDAHULUAN}

Ilmu Pengetahuan Alam (IPA) merupakan ilmu yang berhubungan dengan penyingkapan alam secara sistematis, sehingga IPA tidak belajar kumpulan pengetahuan yang berupa fakta-fakta, konsep-konsep, atau prinsip-prinsip saja tetapi juga merupakan suatu proses penemuan. Sejalan dengan definisi tersebut, tuntutan dalam Pendidikan IPA adalah diharapkan dapat menjadi wahana bagi siswa untuk mempelajari diri sendiri dan alam sekitar, serta prospek pengembangan lebih lanjut dalam menerapkannya di dalam kehidupan sehari-hari. Menurut Kemendikbud (2013), Pendidikan IPA diarahkan untuk menemukan sendiri dan berbuat sehingga dapat membantu siswa untuk memperoleh pemahaman yang lebih mendalam tentang alam sekitar. Dengan demikian, proses pembelajarannya menekankan pada pemberian pengalaman langsung untuk mengembangkan kompetensi agar menjelajahi dan memahami alam sekitar secara ilmiah.

Kemampuan kerja ilmiah penting bagi siswa yang sedang belajar maupun masa depannya. Dalam bekerja ilmiah siswa perlu bersikap kritis, bernalar, dan bersikap ilmiah. Sebaliknya dengan melakukan kegiatan-kegiatan berdasarkan keterampilan proses IPA siswa akan menjadi kritis, kemampuan bernalarnya berkembang, juga sikap ilmiahnya. Kegiatan praktikum menunjang penguasaan konsep atau materi pelajaran, secara penemuan. Selain untuk menunjang penguasaan konsep, kegiatan praktikum juga penting dilakukan agar siswa menjadi termotivasi belajar IPA, dalam kegiatan praktikum dikembangkan keterampilan-keterampilan dasar bereksperimen, dan kegiatan praktikum merupakan wahana pengembangan penyelidikan ilmiah.

Materi IPA yang mempelajari tentang objek dan fenomena alam merupakan hal yang tidak bisa dipisahkan dari keterampilan berpikir. Hal ini disebabkan karena mempelajari objek dan fenomena alam dapat dipahami melalui proses berpikir kritis dan kreatif (Anjarsari, 2014). IPA merupakan ilmu pengetahuan tentang alam yang mempelajari objek, fenomena dan proses yang terjadi di alam. IPA berkaitan dengan cara mencari tahu tentang alam secara sistematis. pembelajaran IPA tidak hanya menekankan produk saja, melainkan juga pada proses penemuan. Melalui proses penemuan tersebut siswa belajar untuk belajar (learn how to learn) yang merupakan inti dari keterampilan berpikir. IPA merupakan proses penting untuk mendekripsikan alam secara akurat dan membuat serta menguji sistem teoritis yang menjelaskan fenomena alam. Perkembangan ilmu pengetahuan abad 21 menuntut individu untuk menjadi sumber daya manusia (SDM) yang berkualitas. Ciri-ciri SDM yang berkualitas adalah mampu mengelola, menggunakan dan mengembangkan keterampilan berpikir (Anjarsari, 2014).

Hasil observasi di SMP Negeri 1 Probolinggo, dalam proses pembelajaran guru IPA menerapkan berbagai metode, seperti demonstrasi, eksperimen, atau diskusi. Ketika melakukan eksperimen, guru menyiapkan lembar kerja yang berisi langkahlangkah kegiatan yang akan dilakukan oleh siswa yaitu mengumpulkan data, menganalisis data, dan membuat kesimpulan. Siswa belum terbiasa merumuskan masalah dan hipotesis, karena guru belum memberi kesempatan kepada siswa untuk mengidentifikasi masalah yang relevan dengan bahan pelajaran dan konteks. Padahal memberi kesempatan siswa untuk mengidentifikasi dan menganalisa permasasalahan yang mereka hadapi, merupakan teknik yang berguna dalam membangun siswa agar mereka terbiasa untuk menemukan suatu masalah. Selain itu partisipasi siswa dalam kegiatan penyelidikan melalui praktikum masih belum maksimal padahal partisipasi tersebut dapat mendorong siswa untuk mengajukan pertanyaan, merumuskan hipotesis, melakukan percobaan, menggunakan alat untuk mengumpulkan data, menganalisis data, menyimpulkan dan berargumen, untuk mengembangkan kemampuan kerja ilmiah siswa dan membuat siswa belajar secara aktif dalam menemukan konsep.

Berdasarkan kenyataan tersebut peneliti berupaya agar kemampuan kerja ilmiah sesuai dengan harapan. Salah satu alternatif pemecahan masalah tersebut adalah setiap proses pembelajaran guru memberi kesempatan pada siswa untuk mengidentifikasi sebanyak mungkin masalah yang relevan dengan bahan pelajaran atau sesuai konteks, kemudian salah satunya dipilih dan dirumuskan dalam bentuk rumusan masalah. Tujuannya agar siswa terbiasa menemukan masalah dan merumuskan hipotesisnya. Guru perlu merancang suatu pembelajaran IPA agar terwujud tujuan pembelajaran sesuai yang diharapkan, yaitu agar siswa aktif dalam membangun pengetahuannya sendiri, serta mampu menggunakan penalarannya dalam memahami dan memecahkan masalah yang dihadapi. Pembelajaran yang menekankan pada keaktifan siswa untuk menemukan konsep sendiri diantaranya adalah metode discovery (Kemendikbud, 2013). Pembelajaran Discovery merupakan suatu model pembelajaran yang dikembangkan oleh Bruner berdasarkan pada pandangan kognitif tentang pembelajaran dan prinsip-prinsip konstruktivis (Depdiknas, 2005). Menurut (Slavin, 1994) dalam (Depdiknas, 2005), siswa belajar melalui keterlibatan aktif dengan 
konsep-konsep dan prinsip-prinsip, dan guru mendorong siswa untuk mendapatkan pengalaman dengan melakukan kegiatan yang memungkinkan mereka menemukan konsep dan prinsip-prinsip untuk diri mereka sendiri.

Pembelajaran Discovery lebih menekankan pada ditemukannya konsep atau prinsip yang sebelumnya tidak diketahui. Prinsip belajar yang nampak jelas dalam Discovery adalah materi atau bahan pelajaran yang akan disampaikan tidak disampaikan dalam bentuk final akan tetapi siswa didorong untuk mengidentifikasi apa yang ingin diketahui dilanjutkan dengan mencari informasi sendiri kemudian mengorganisasi atau membentuk (konstruktif) apa yang mereka ketahui dan mereka pahami dalam suatu bentuk akhir (Kemendikbud, 2013: 264). Menurut Istiana (2015), belajar penemuan atau Discovery merupakan suatu pembelajaran yang melibatkan siswa dalam pemecahan masalah untuk pengembangan pengetahuan dan ketrampilan. Melalui penemuan, siswa belajar secara intensif dengan mengikuti metode investigasi ilmiah di bawah supervisi guru. Jadi belajar dirancang, disupervisi, diikuti metode investigasi. Tiga ciri utama dari belajar menemukan (Discovery) yaitu: mengeksplorasi dan memecahkan masalah untuk menciptakan, menggabungkan dan menggeneralisasikan pengetahuan; berpusat pada siswa; dan kegiatan untuk menggabungkan pengetahuan baru dan pengetahuan yang sudah ada

Jurnal belajar adalah dokumen yang dibuat siswa dan berisi refleksi setelah mengalami proses belajar. Menurut Park dalam Fadillia (2012) jurnal belajar berpotensi meningkatkan minat dan keterlibatan siswa dengan materi dan mendorong siswa lebih bertanggung jawab terhadap pembelajaran, sehingga menjadikan lebih aktif. Penulisan jurnal belajar merupakan pendukung kegiatan pembelajaran. Bagi guru jurnal belajar siswa menjadi masukan berharga. Guru dapat mengetahui apakah pembelajaran yang dilaksanakan menarik, materi dikuasai siswa dan apakah ada siswa yang menulis tentang materi yang dipelajari dari sumber lain dan lain sebagainya. Sementara itu bagi siswa manfaatnya antara lain; tempat bertanya kepada gurunya, tempat menunjukkan bahwa siswa tersebut mengetahui lebih dalam dari yang diajarkan oleh guru atau mungkin ada juga siswa yang tidak senang dengan metode yang digunakan gurunya, dan lain sebagainya. Siswa sebagai calon anggota masyarakat ilmiah perlu dibimbing dan dibiasakan mengekspresikan hasil refleksinya terhadap pembelajaran, oleh sebab itu guru wajib membina siswa tersebut. Sebagai pendukung kegiatan pembelajaran, penulisan jurnal belajar sebagai refleksi pembelajaran diharapkan dapat melatih siswa belajar secara aktif untuk menemukan sesuatu yang berhubungan dengan permasalahan yang dihadapi, dengan demikian siswa terlatih menghubungkan masalah dengan pengetahuan yang telah dimiliki.

Dengan mengaplikasikan pembelajaran Discovery secara berulang ulang dapat meningkatkan kemampuan penemuan diri individu yang bersangkutan. Model Pembelajaran Discovery menuntut siswa untuk aktif dan kreatif, daripada pembelajaran yang pasif. Mengubah pembelajaran yang teacher oriented ke student oriented. Jurnal belajar merupakan salah satu sarana pembelajaran yang memiliki banyak fungsi. Salah satu fungsi jurnal belajar adalah jembatan komunikasi antara guru dengan siswa. Berkaitan dengan fungsi tersebut, maka jurnal belajar dianggap sebagai sarana yang tepat untuk mereduksi permasalahan yang muncul dalam pembelajaran, sehingga mutu pembelajaran di kelas dapat ditingkatkan.

\section{METODE}

Penelitian ini merupakan Penelitian Tindakan Kelas (PTK) yang dilakukan dengan dua siklus terdiri dari tahap perencanaan, pelaksanaan, observasi, dan refleksi yang dilakukan di setiap siklus. Subyek penelitian adalah siswa kelas VIII.1 SMPN 1 Probolinggo yang berjumlah 27 orang (16 perempuan dan 11 laki-laki). Pengumpulan data dalam penelitian ini dilakukan dengan metode dokumentasi dan observasi. Data dalam penelitian ini meliputi data: (1) keterlaksanaan pembelajaran Discovery disertai penulisan jurnal belajar, (2) jurnal belajar, dan (3) kemampuan kerja ilmiah. Berikut data, sumber data, dan instrumen yang digunakan dalam penelitian ini disajikan dalam Tabel 1 berikut.

Tabel 1. Data, Sumber Data, dan Instrumen

\begin{tabular}{llll}
\hline No & Jenis Data & Sumber Data & Instrumen \\
\hline 1. & Keterlaksanaan pembelajaran & Guru dan Siswa & Lembar observasi keterlaksanaan \\
& Discovery disertai penulisan & & pembelajaran, catatan lapangan \\
& jurnal belajar & & Rubrik penilaian jurnal belajar \\
2. & Jurnal belajar & Siswa & Lembar observasi unjuk kerja \\
3. & Kemampuan kerja ilmiah & Siswa & \\
\hline
\end{tabular}


Data yang dikumpulkan dalam penelitian ini selanjutnya dianalisis secara deskriptif. Analisis ini dilakukan untuk mengetahui keterlaksanaan pembelajaran, kemampuan menulis jurnal belajar, dan kemampuan kerja ilmiah.

\section{HASIL DAN PEMBAHASAN Hasil Penelitian Siklus I Perencanaan}

Pada tahap perencanaan disiapkan Silabus, RPP, LKS, Lembar Observasi Keterlaksanaan Pembelajaran, Lembar Observasi Kemampuan Kerja Ilmiah, Catatan Lapangan, Rubrik Penilaian Jurnal Belajar. Materi pada siklus I adalah Sistem Gerak pada Manusia

\section{Pelaksanaan tindakan}

Siklus I dilaksanakan sebanyak 3 kali pertemuan. Pertemuan pertama hari Selasa tanggal 30 Agustus 2016, pertemuan kedua hari Rabu tanggal 31 Agustus 2016, dan pertemuan ketiga hari Selasa tanggal 6 September 2016. Siklus I mempelajari materi Sistem Gerak pada Manusia. Pertemuan pertama materi Rangka Manusia, pertemuan kedua materi Sendi, dan pertemuan ketiga materi Otot. Setiap pertemuan guru menerapkan langkah-langkah pembelajaran Discovery disertai penulisan jurnal belajar yaitu: 1) stimulation (pemberian rangsang) untuk mengembangkan dan membantu siswa dalam mengeksplorasi bahan. Guru memberi pertanyaan "mengapa tubuh kita bisa duduk dengan tegak dan apa yang membuatnya demikian?". Guru memancing siswa agar mengajukan pertanyaan yang berkaitan dengan posisi duduk tegak temannya dan memberi kesempatan pada siswa untuk melakukan eksplorasi berdasarkan pertanyaan yang diajukan. 2) problem statement (mengidentifikasi masalah) yang relevan dengan bahan pelajaran, kemudian salah satunya dipilih dan dirumuskan dalam bentuk hipotesis. 3) data collection (mengumpulkan data) berbagai informasi yang relevan, membaca buku, mengamati obyek torso rangka manusia. Guru membimbing dan mengarahkan siswa untuk melanjutkan kegiatan mencari dan mengumpulkan data. Secara berkelompok siswa mengamati rangka tubuh manusia untuk mengidentifikasi jenis-jenis tulang yang menyusun rangka tubuh manusia, mengelompokkan dan menyebutkan fungsi masing-masing tulang. 4) data processing (mengolah data) dari hasil pengamatan. Pengolahan data juga dikaitkan untuk menjawab pertanyaan-pertanyaan yang ada di LKS. 5) verification (pembuktian) dengan melakukan pemeriksaan secara cermat untuk membuktikan benar atau tidaknya hipotesis yang ditetapkan tadi dengan temuan alternatif dan dihubungkan dengan hasil pengolahan data. Siswa berdiskusi untuk melakukan verifikasi antara data hasil percobaan/pengamatan yang dilakukan dengan data-data pada buku sumber yang relevan. 6) generalization (menarik kesimpulan) yang dapat dijadikan prinsip umum dan berlaku untuk semua kejadian atau masalah yang sama, dengan memperhatikan hasil verifikasi. Salah satu kelompok mempresentasikan hasil pengamatan dan diskusi yang sudah dilakukan, kelompok yang lain memberikan tanggapan, pendapat, pertanyaan, dan saran. Guru membimbing siswa untuk menarik kesimpulan dan memberikan penguatan terhadap materi yang sudah dipelajari; refleksi jurnal belajar yaitu menulis jurnal belajar tentang pembelajaran yang telah dilaksanakan yaitu bagaimana perasaan/ pengalamn selama pembelajaran, materi yang belum dipahami, materi yang sudah dipahami, kendala yang dialami selama proses pembelajaran, bagaimana cara mengatasi kendala tersebut, manfaat apa yang diperoleh setelah mengikuti pembelajaran, harapan apa yang ingin dicapai dan bagaimana upaya yang dilakukan untuk pengayaan materi.

Rangkaian kegiatan diatas juga dilakukan untuk pertemuan kedua dan ketiga. Dua orang observer melakukan pengamatan dengan mengisi lembar observasi keterlaksanaan pembelajaran, lembar observasi kemampuan kerja ilmiah dan lembar catatan lapangan yang digunakan untuk mencatat hal-hal yang berkaitan dengan aktivitas yang belum terekam dalam lembar observasi. Pada pertemuan keempat dilaksanakan tes tulis untuk mengetahui tingkat pencapaian hasil belajar siswa setelah mempelajari materi Sistem Gerak pada Manusia.

\section{Hasil observasi dan evaluasi \\ Aktivitas guru selama pembelajaran}

Data hasil observasi keterlaksanaan pembelajaran Discovery disertai penulisan jurnal belajar bisa dilihat pada Tabel 2 berikut. 
Tabel 2. Hasil Observasi Keterlaksanaan Pembelajaran Discovery disertai Penulisan Jurnal Belajar Siklus I

\begin{tabular}{lccc}
\hline Penentuan Keberhasilan & \multicolumn{3}{c}{ Rerata Skor Keterlaksaaan Pembelajaran } \\
\cline { 2 - 4 } Tindakan & TM 1 & TM 2 & TM 3 \\
\hline Langkah 1 & 3 & 3 & 4 \\
Langkah 2 & 3 & 4 & 4 \\
Langkah 3 & 4 & 4 & 4 \\
Langkah 4 & 3 & 3 & 4 \\
Langkah 5 & 4 & 4 & 4 \\
Langkah 6 & 4 & 3 & 3 \\
Langkah 7 & 3 & 3.57 & 3.86 \\
\hline Rata -rata & 3.43 & $89.25 \%$ & $96.50 \%$ \\
\hline Rata-rata dalam \% & $85.75 \%$ & $90.50 \%$ & \\
\hline Rata-rata & & & \\
\hline Kerangan:
\end{tabular}

Keterangan:

Kriteria presentasi: $80 \%-100 \%=$ Sangat baik, $60 \%-79 \%=$ Baik, $55 \%-59 \%=$ Cukup, $50 \%-54 \%=$ Kurang, dan $\leq 49 \%=$ Sangat kurang

Berdasarkan skor data observasi keterlaksanaan pembelajaran Discovery disertai penulisan jurnal belajar diperoleh rata-rata persentase keterlaksanaan pembelajaran siklus 1 sebesar $90.50 \%$ dengan rincian pertemuan ke-1 sebesar $85.75 \%$, pertemuan ke-2 sebesar $89.25 \%$, dan pertemuan ke-3 sebesar $96.50 \%$. Keterlaksanaan pembelajaran pada siklus I hanya tercapai $90.50 \%$ disebabkan ada beberapa langkah yang belum maksimal dilaksanakan yaitu: a) Pelaksanaan pertemuan pertama memerlukan waktu lebih lama karena siswa belum terbiasa dengan pembelajaran Discovery disertai penulisan jurnal belajar, meskipun sebelumnya sudah diberi penjelasan tentang bagaimana model pembelajaran tersebut. Contohnya adalah pada saat mengajukan masalah dan merumuskan hipotesisnya. b) Pada tahap stimulation (menciptakan situasi), pertemuan pertama dan kedua, ketika guru menggali pengetahuan awal siswa dengan memberikan pertanyaan. Guru memberikan ilustrasi pertanyaan pengantar untuk mengaitkan konsep yang akan dipelajari dengan konsep yang telah dimiliki siswa. Masih ada beberapa siswa yang belum berkonsentrasi penuh sehingga tidak segera menanggapi pertanyaan pemusatan perhatian dan motivasi dari guru. c) Pada tahap kedua yaitu Problem statement (pertanyaan/identifikasi masalah), pertemuan pertama siswa masih kesulitan merumuskan masalah dan hipotesisnya sehingga guru perlu menjelaskan lagi bagaimana cara merumuskan masalah dan hipotesis yang benar. d) Pada tahap empat pertemuan pertama dan kedua beberapa siswa tidak melakukan diskusi secara maksimal dan ada beberapa yang bergurau sehingga tidak segera menyelesaikan tahap ini. e) Pada tahap akhir pembelajaran, yaitu pada saat refleksi penulisan jurnal belajar masih ada beberapa siswa yang melihat refleksi temannya dan tidak segera menulis refleksi jurnal belajarnya sendiri.

\section{Penulisan jurnal belajar}

Penulisan jurnal belajar dilakukan sebagai hasil refleksi siswa selama pembelajaran. Guru memeriksa jurnal belajar untuk mengetahui respon siswa terhadap kegiatan pembelajaran berdasarkan kelengkapan, tata bahasa, dan kesesuaian isi jurnal dengan kegiatan pembelajaran yang dilaksanakan. Skor yang diperoleh berdasarkan lembar observasi jurnal belajar kemudian dibagi skor maksimal dan dikalikan 100. Hasil penghitungan kemudian digunakan untuk menentukan kategori keterampilan siswa dalam menulis jurnal belajar sesuai yang ditunjukkan Tabel 3 berikut.

Tabel 3. Hasil Penulisan Jurnal Belajar Siswa pada Siklus 1

\begin{tabular}{ccccc}
\hline No. & Katagori & Rentang Skor & Jumlah Siswa & No Absen \\
\hline 1 & Sangat Baik & $80-100$ & 3 & $3,18,19$ \\
\hline 2 & Baik & $60-79$ & 15 & $1,2,5,7,9,10,11,13,15,16$, \\
& & & $4,20,24,26,27$ \\
\hline 3 & Cukup & $40-59$ & 9 & 0 \\
\hline 4 & Kurang & $20-39$ & 0 & \\
\hline
\end{tabular}




\begin{tabular}{ccccc}
\hline No. & Katagori & Rentang Skor & Jumlah Siswa & No Absen \\
\hline 5 & Sangat Kurang & $0-19$ & 0 & 0 \\
\hline
\end{tabular}

\section{Kemampuan kerja ilmiah}

Kemampuan kerja ilmiah dalam penelitian ini adalah kemampuan siswa dalam melakukan serangkaian kegiatan pembelajaran untuk mendapatkan pengetahuan dan pemahaman terhadap materi yang dipelajari. Data kemampuan kerja ilmiah diperoleh dari lembar observasi kemampuan kerja ilmiah. Tabel 4 berikut adalah Rata-rata Skor \& Prosentase Hasil Observasi Kemampuan Kerja Ilmiah Siklus I

Tabel 4. Rata-rata Skor \& Prosentase Hasil Observasi Kemampuan Kerja Ilmiah Siklus I

\begin{tabular}{cccc}
\hline $\begin{array}{c}\text { Jenjang Kemampuan } \\
\text { Unjuk Kerja }\end{array}$ & Skor & Prosentase (\%) & Kategori \\
\hline $\begin{array}{c}\text { Merumuskan masalah } \\
\text { \& hipotesis }\end{array}$ & 2.7 & 67.50 & Cukup \\
\hline $\begin{array}{c}\text { Melakukan kegiatan/ } \\
\text { percobaan }\end{array}$ & 2.9 & 72.50 & Baik \\
\hline $\begin{array}{c}\text { Mengolah data hasil } \\
\text { pengamatan/ percobaan }\end{array}$ & 3.0 & 75.00 & Baik \\
\hline Menyusun kesimpulan & 3.0 & 75.00 & Baik \\
\hline $\begin{array}{c}\text { Mempresenta-sikan dan } \\
\text { menanggapi presentasi } \\
\text { hasil pengamatan/ } \\
\text { percobaan }\end{array}$ & 3.1 & 77.50 & Baik \\
\hline Rata-rata & 2.94 & & Baik \\
\hline
\end{tabular}

Berdasarkan Tabel 4. di atas dapat diketahui bahwa rata-rata hasil kemampuan kerja ilmiah berdasarkan hasil observasi pada siklus I sebesar $73.50 \%$ dengan taraf keberhasilan termasuk dalam kategori sangat baik.

\section{Refleksi}

Berdasarkan hasil siklus I, penerapan pembelajaran Discovery disertai penulisan jurnal belajar memiliki kekurangan sebagai berikut:

1. Keterlaksanaan pembelajaran mencapai 90.50\% masih harus ditingkatkan karena ada pelaksanaan beberapa langkah yang belum sempurna.

2. Membutuhkan waktu lebih lama dibandingkan dengan metode langsung. Hal ini disebabkan untuk memahami strategi ini dibutuhkan tahapan-tahapan yang panjang dan kemampuan memanfaatkan waktu dengan sebaik-baiknya.

3. Siswa masih mengalami kesulitan dan memerlukan waktu yang lama untuk mengajukan masalah dan merumuskan hipotesisnya.

4. Hasil observai penulisan jurnal belajar belum maksimal karena hanya 3 siswa yang memperoleh katagori sangat baik, 15 siswa memperoleh katagori baik, dan 9 siswa memperoleh katagori cukup.

5. Hasil observasi kemampuan kerja ilmiah masih perlu ditingkatkan meskipun rata- ratanya sudah dalam katagori baik, tetapi ketika siswa merumuskan masalah dan hipotesis masih didapat skor 2.7 atau $67.50 \%$ dengan katagori cukup.

\section{Hasil Penelitian Siklus II \\ Perencanaan}

Melihat kekurangan-kekurangan pada pelaksanaan pembelajaran Discovery disertai penulisan jurnal belajar pada siklus I, maka perlu dibuat rencana perbaikan untuk melanjutkan ke siklus II. Perbaikan pada siklus II berupa:

1. Pelaksanaan pembelajaran Discovery disertai penulisan jurnal belajar yang belum optimal terlaksana pada siklus I perlu dioptimalkan pada pembelajaran siklus II.

2. Pengelolaan waktu lebih diperketat.

3. Guru lebih intensif memberi bimbingan dalam merumuskan masalah dan hipotesisnya.

4. Guru perlu menjelaskan kembali bagaimana penulisan jurnal belajar yang benar sesuai format yang tersedia sehingga bisa menggambarkan keadaan yang sebenarnya selama proses pembelajaran, ditulis rapi dan lengkap, serta dengan tata bahasa yang baik dan benar.

5. Untuk meningkatkan kemampuan kerja ilmiah yang maksimal, guru perlu mencari jenjang 
indikator kemampuan kerja ilmiah yang mana yang nilainya masing rendah dan diperbaiki pada siklus berikutnya.

\section{Pelaksanaan tindakan}

Siklus II dilaksanakan sebanyak 2 kali pertemuan. Pertemuan pertama hari Selasa, 13 September 2016, pertemuan kedua hari Rabu tanggal 14 September 2016. Tahapan pembelajaran yang digunakan pada siklus II sama dengan siklus I dengan materi Pesawat Sederhana, meliputi tahapan plan, act \& observe, dan reflect.

\section{Hasil observasi dan evaluasi}

Aktivitas guru selama pembelajaran

Data hasil observasi keterlaksanaan pembelajaran Discovery disertai penulisan jurnal belajar pada siklus II bisa dilihat pada Tabel 5 berikut.

Tabel 5. Hasil Observasi Keterlaksanaan Pembelajaran Discovery disertai Penulisan Jurnal Belajar Siklus II

\begin{tabular}{ccc}
\hline Penentuan Keberhasilan & \multicolumn{2}{c}{ Rerata Skor Keterlaksaaan Pembelajaran } \\
\cline { 2 - 3 } Tindakan & TM 1 & TM 2 \\
\hline Langkah 1 & 4 & 4 \\
Langkah 2 & 4 & 4 \\
Langkah 3 & 4 & 4 \\
Langkah 4 & 4 & 4 \\
Langkah 5 & 4 & 4 \\
Langkah 6 & 4 & 4 \\
Langkah 7 & 3 & 4.00 \\
\hline Rata -rata & 3.86 & $100 \%$ \\
\hline Rata-rata & & \\
dalam \% & $96.50 \%$ & \\
\hline Rata-rata & \multicolumn{2}{c}{$98.25 \%$} \\
\hline
\end{tabular}

Keterangan:

Kriteria presentasi: $80 \%-100 \%=$ Sangat baik, $60 \%-79 \%=$ Baik, $55 \%-59 \%=$ Cukup, $50 \%-54 \%=$ Kurang, dan $\leq 49 \%=$ Sangat kurang

Berdasarkan data observasi keterlaksanaan pembelajaran Discovery disertai penulisan jurnal belajar diperoleh rata-rata persentase keterlaksanaan pembelajaran siklus II sebesar 98.25\% dengan rincian pertemuan ke-1 sebesar $96.50 \%$, dan pertemuan ke-2 sebesar $100 \%$.

\section{Penulisan jurnal belajar}

Hasil observasi keterampilan siswa dalam menulis jurnal belajar pada siklus II ditunjukkan Tabel 6 berikut.

Tabel 6. Hasil Penulisan Jurnal Belajar Siswa pada Siklus 1I

\begin{tabular}{|c|c|c|c|c|}
\hline No. & Katagori & Rentang Skor & Jumlah Siswa & No Absen \\
\hline 1 & Sangat Baik & $80-100$ & 15 & $\begin{array}{c}1,2,3,10,11,13,15,17,18 \\
19,20,22,26,27\end{array}$ \\
\hline 2 & Baik & $60-79$ & 9 & $4,5,7,8,9,12,21,23,24$ \\
\hline 3 & Cukup & $40-59$ & 3 & $6,14,25$ \\
\hline 4 & Kurang & $20-39$ & 0 & 0 \\
\hline 5 & Sangat Kurang & $0-19$ & 0 & 0 \\
\hline
\end{tabular}

\section{Kemampuan kerja ilmiah}

Berdasarkan rata-rata skor hasil observasi kemampuan kerja ilmiah untuk tiap pertemuan pada siklus II, didapatkan rata-rata skor dan prosentasenya pada satu siklus seperti pada Tabel 7 berikut.

Tabel 7. Rata-rata Skor \& Prosentase Hasil Observasi Kemampuan Kerja Ilmiah Siklus II

\begin{tabular}{cccc}
\hline $\begin{array}{c}\text { Jenjang Kemampuan } \\
\text { Unjuk Kerja }\end{array}$ & Skor & Prosentase (\%) & Kategori \\
\hline $\begin{array}{c}\text { Merumuskan masalah \& } \\
\text { hipotesis }\end{array}$ & 3.8 & 95.00 & Sangat Baik \\
\hline
\end{tabular}




\begin{tabular}{cccc}
\hline $\begin{array}{c}\text { Melakukan kegiatan/ } \\
\text { percobaan }\end{array}$ & 3.9 & 97.50 & Sangat Baik \\
\hline $\begin{array}{c}\text { Mengolah data hasil } \\
\text { pengamatan/ percobaan }\end{array}$ & 3.9 & 97.50 & Sangat Baik \\
\hline Menyusun kesimpulan & 3.8 & 95.00 & Sangat Baik \\
\hline $\begin{array}{c}\text { Mempresenta-sikan dan } \\
\text { menanggapi presentasi } \\
\text { hasil pengamatan/ } \\
\text { percobaan }\end{array}$ & 3.9 & 97.50 & Sangat Baik \\
\hline Rata-rata & 3.86 & 96.50 & Sangat Baik \\
\hline
\end{tabular}

Berdasarkan Tabel 7 di atas dapat diketahui bahwa rata-rata hasil kemampuan kerja ilmiah berdasarkan hasil observasi pada siklus II sebesar $96.50 \%$ dengan taraf keberhasilan termasuk dalam kategori sangat baik.

\section{Refleksi}

Berdasarkan paparan data pada tahap observasi diatas, keterlaksanaan pembelajaran pada siklus II sebesar $98.25 \%$, kemampuan menulis jurnal belajar mengalami peningkatan untuk katagori sangat baik, baik dan cukup, kemampuan kerja ilmiah rata-rata sebesar $96.50 \%$.

\section{Pembahasan Hasil Penelitian}

Hasil analisa data dari pelaksanaan pembelajaran Discovery disertai penulisan jurnal belajar dapat dilihat pada Tabel 8 .

Tabel 8. Hasil Analisa Data dari Pelaksanaan Pembelajaran Discovery disertai Penulisan Jurnal Belajar

\begin{tabular}{llcc}
\hline No. & \multicolumn{1}{c}{ Komponen } & Hasil (\%) \\
\cline { 3 - 4 } & & 90.50 & Siklus II \\
\hline 1. & Keterlaksanaan Pembelajaran & 73.50 & 98.25 \\
\hline 2. & Kemampuan Kerja Ilmiah & & 96.50 \\
\hline
\end{tabular}

Keterlaksanaan pembelajaran Discovery disertai penulisan jurnal belajar pada siklus I masih $90.50 \%$, karena memerlukan waktu yang lebih lama terutama pada saat merumuskan masalah dan hipotesis. Hal ini sesuai dengan pendapat Sanjaya (2006) yang mengatakan bahwa salah satu kelemahan dari pembelajaran penemuan adalah memerlukan waktu yang panjang dalam pelaksanaannya. Akan tetapi dengan usaha yang keras dan beberapa pengalaman sebagai latihan maka pembelajaran dapat dilaksanakan dengan baik dan tepat sesuai dengan alokasi waktu yang disediakan. Keterlaksanaan pembelajaran Discovery disertai penulisan jurnal belajar pada siklus II meningkat $7.75 \%$ yaitu dari $90.50 \%$ menjadi $98.25 \%$. Berdasarkan peningkatan keterlaksanaan pembelajaran tersebut, dapat diambil kesimpulan bahwa peningkatan persentase keterlaksanaan pembelajaran Discovery disertai penulisan jurnal belajar karena peneliti melakukan perbaikan pembelajaran. Kekurangan-kekurangan yang terjadi pada siklus I diperbaiki pada siklus II. Hal ini sejalan dengan pernyataan Arends (2008) bahwa keterlaksanaan pembelajaran meningkat karena pembenahan dan perbaikan pembelajaran yang dilakukan, dan pendapat Albab (2012) dalam Suprihatin (2014) menyatakan bahwa pembelajaran Discovery menempatkan siswa tepat di tengah dalam proses pembelajaran, sehingga siswa secara aktif mencari informasi sendiri melalui observasi, eksperimen, aktif berdiskusi dan bertukar pendapat untuk membuktikan teori atau fakta tentang materi yang sedang dipelajari guna mendapatkan suatu kesimpulan.

Penulisan jurnal belajar dilakukan sebagai hasil refleksi siswa selama pembelajaran. Jurnal belajar akan diperiksa oleh guru untuk mengetahui respon siswa terhadap kegiatan pembelajaran yang sudah dilaksanakan berdasarkan kelengkapan, tata bahasa, dan kesesuaian isi jurnal dengan kegiatan pembelajaran yang dilaksanakan. Hasil analisis pada siklus I dan siklus II menunjukkan adanya peningkatan kemampuan siswa dalam menulis jurnal belajar. Pada siklus I yang memperoleh katagori skor sangat baik 3 orang, katagori skor baik 15 orang, dan katagori sekor cukup 9 orang. Pada siklus II yang memperoleh katagori skor sangat baik 15 orang, katagori skor baik 9 orang, dan katagori sekor cukup 3 orang. Ini sejalan dengan hasil penelitian Fadilia (2012) yang menyatakan bahwa jurnal belajar yang dibuat oleh siswa berfungsi sebagai sarana untuk menfasilitasi proses identifikasi kesulitan belajarnya yaitu konsep-konsep belajar yang belum dimengerti.

Dengan mengetahui kesulitan belajarnya lebih awal juga dapat lebih cepat melakukan upaya 
untuk mengatasi kesulitan belajar tersebut, sehingga pada saat seluruh konsep yang belum dimengerti tersebut telah teratasi. Hal tersebut menyebabkan hasil belajar kognitif lebih baik karena dengan mengetahui kesulitan dalam belajarnya membuat termotivasi untuk mengatasi kesulitan belajarnya. Pendapat ini didukung oleh penelitian Farug (2012) yang menyatakan bahwa penugasan menulis jurnal belajar merupakan rangkaian pembelajaran kreatif. Melalui penugasan menulis jurnal belajar, siswa dapat menjadi lebih kreatif karena dalam menulis jurnal belajar diperlukan kemampuan mengeksplorasi ide dan gagasan serta kemampuan melakukan refleksi diri dan Junaidi ((2013) yang menyimpulkan bahwa penguasaan konsep siswa meningkat dengan penulisan jurnal belajar sebagai refleksi pembelajaran.

Kemampuan kerja ilmiah mengalami peningkatan dari siklus I ke siklus II sebesar $23 \%$, dari $73.50 \%$ menjadi $96.50 \%$. Ini sejalan dengan penelitian Ali (2011) yang menyatakan bahwa implementasi pembelajaran penemuan dengan pemberian umpan balik terhadap jurnal belajar IPA, tidak hanya menolong siswa dalam memhami materi, tetapi juga meningkatkan rasa dan sikap positif selama dan setelah pembelajaran berlangsung, yang pada akhirnya berpengaruh pada peningkatan kemampuan kerja ilmiah. Juga didukung oleh penelitian Adji dan Huda (2016) menyatakan bahwa peningkatan persentase hasil rata-rata kerja ilmiah siswa berasal dari observasi kerja ilmiah selama pembelajaran berdasarkan aspek kerja ilmiah yang dilatihkan, yaitu menggunakan alat dan bahan, mengumpulkan data, menganalisis data, menyimpulkan dan mengkomunikasikan hasil eksperimen.

Berdasarkan hasil tersebut akhirnya pembelajaran Discovery disertai penulisan jurnal belajar yang diterapkan pada siswa kelas VIII.1 SMP Negeri 1 Probolinggo dapat meningkatkan kemampuan kerja ilmiah. Berdasarkan uraian di atas, terjadinya peningkatan kemampuan kerja ilmiah karena berbagai faktor. Salah satu adalah bahwa proses pembelajaran harus dikemas menjadi proses merekonstruksi, bukan menerima informasi/pengetahuan dari guru. Siswa akan membangun sendiri pengetahuannya melalui keterlibatan secara aktif dalam proses pembelajaran. Hal ini juga didukung oleh penelitian Ilahi (2012) dalam Widiadnyana (2014) bahwa penerapan pembelajaran penemuan memiliki kelebihan-kelebihan membantu siswa untuk memperbaiki dan meningkatkan keterampilan dan proses kognitif. Selain itu pengetahuan yang diperoleh sangat pribadi dan ampuh karena menguatkan pengertian, ingatan dan transfer (Melani, 2012 dalam Widiadnyana
2014). Menurut Rustaman (2005) perlunya guru IPA merancang program pembelajaran IPA yang berbasis penemuan telah ditekankan sejak lama oleh para pakar pendidikan dan pakar pendidikan IPA. Sardiman (2010) mengemukakan bahwa pengetahuan riil bagi para siswa adalah sesuatu yang dibangun atau ditemukan oleh siswa itu sendiri. Jadi pengetahuan bukanlah seperangkat fakta, konsep atau kaidah yang diingat siswa, tetapi siswa harus merekonstruksi pengetahuan itu kemudian memberi makna pada pengalaman nyata. Siswa dilatih untuk memecahkan masalah, menemukan sesuatu yang berguna bagi dirinya dan bergulat dengan ide-ide kemudian mampu merekonstruksinya.

\section{PENUTUP}

Berdasarkan data dan pembahasan hasil penelitian maka ditarik kesimpulan bahwa pembelajaran Discovery disertai penulisan jurnal belajar dapat meningkatkan kemampuan kerja ilmiah kelas VIII.1 SMP Negeri 1 Probolinggo. Bagi guru hendaknya memiliki pemahaman yang kongkret mengenai pembelajaran Discovery disertai penulisan jurnal belajar dan penerapannya dalam proses pembelajaran IPA di kelas sehingga dapat digunakan sebagai acuan untuk memperbaiki proses pembelajaran dan pengelolaan pembelajaran di kelas dan sebelum melaksanakan pembelajaran perlu merencanakan dengan matang, dan mempertimbangkan alokasi waktu agar pelaksanaan pembelajaran sesuai rencana.

\section{DAFTAR PUSTAKA}

Aji, S.D \& Hudha, M.N (2016). Kerja Ilmiah Siswa SMP dan SMA melalui Authentic Problem Based Learning (APBL). Jurnal Inspirasi Pendidikan Universitas Kanjuruhan Malang. Pendidikan Fisika, Fakultas Sains dan Teknologi, Universitas Kanjuruhan Malang

Ali, T.G.P. 2011. Implementasi Pembelajaran Inkuiri dan Umpan Balik Terhadap Jurnal Belajar untuk Meningkatkan Kemampuan kerja ilmiah dan Prestasi Belajar IPA pada Siswa Kelas VII B SMP Negeri 5 Probolinggo. Tesis tidak diterbitkan. Malang: PPs Universitas Negeri Malang.

Anjarsari, P. 2014. Pentingnya Melatih Keterampilan Berpikir (Thinking Skills) dalam pembelajaran IPA SMP. Makalah disampaikan dalam PPM "Optimalisasi Implementasi Kurikulum 2013 denganWorkshop Pengembangan LKS IPA Berpendekatan Guided-Inquiry untuk Mengembangkan Thinking Skills 
dan Sikap Ilmiah Siswa”. Yogyakarta: UNY.

Arends, R.I. 2008. Learning to Teach (Belajar untuk Mengajar) (7).1 Penerjemah Helly Prayitno Soetjipto. Yogyakarta: Pustaka Belajar.

Depdiknas. 2005. Ilmu Pengetahuan Alam Materi Pelatihan Terintegrasi. Jakarta: Direktorat Jendral Pendidikan Dasar dan Menengah.

Farug, H. 2012. Implementasi Pembelajaran Kooperatif Think Pair Share (TPS) dan Penugasan Menulis Jurnal Belajar untuk Meningkatkan Keterampilan Metakognitif dan Hasil Belajar IPA pada Siswa Kelas VIII A SMP Negeri 5 Probolinggo. Tesis tidak diterbitkan. Malang: PPs Universitas Negeri Malang.

Fadilia, A. 2012. Pengaruh Pembuatan Jurnal Belajar dalam Pendekatan Jelajah Alam Sekitar (JAS) terhadap Hasil Belajar Siswa Materi Ekosistem. Skripsi tidak diterbitkan. Semarang: Universitas Negeri Semarang.

Istiana, G.A. 2015. Penerapan Model Pembelajaran Discovery untuk Meningkatkan Aktivitas dan Prestasi Belajar Pokok Bahasan Larutan Penyangga pada Siswa Kelas XI IPA Semester II SMAN 1 Ngemplak Tahun Pelajaran 2013-2014. Jurnal Pendidikan Kimia (JPK), Vol. 4 No. 2 Tahun 2015 Program Studi Pendidikan Kimia Universitas Sebelas Maret

Junaidi, E. 2013. Penerapan Pembelajaran dengan Menggunakan Jurnal Belajar untuk Meningkatkan Prestasi Belajar Bangun Ruang Pada Siswa SMP Negeri 10 Malang Kelas VIII-H. Skripsi tidak diterbitkan. Malang: Universitas Negeri Malang

Kemendikbud. 2013. Materi Pelatihan Guru Implementasi Kurikulum 2013. Jakarta: Badan Pengembangan Sumber Daya Manusia Pendidikan dan Kebudayaan dan Penjaminan Mutu Pendidikan

Rustaman, N. 2005. Perkembangan Penelitian Pembelajaran Berbasis Inkuiri dalam Pembelajaran Sains. Makalah dipresentasikan dalam Seminar Nasional II Himpunan Ikatan Sarjana dan Pemerhati Pendidikan IPA Indonesia Bekerjasama dengan FPMIPA Universitas Pendidikan Indonesia, Bandung, 22-23 Juli 2005.

Sanjaya, W. 2006. Strategi Pembelajaran Berorientasi Standar Proses Pendidikan. Jakarta: Kencana Penada Media.

Sardiman, A. M. 2010. Interaksi dan Motivasi Belajar Mengajar. Jakarta: Rajawali Press.

Suprihatin, dkk. 2014. Aktivitas dan Hasil Belajar Siswa pada Materi Sistem Pencernaan dengan Penerapan Strategi Pembelajaran Discovery Learning. Unnes Journal of Biology Education 3 (3) (2014) 275-282. Jurusan Biologi, FMIPA Universitas Negeri Semarang, Indonesia

Widiadnyana, I.W. 2014. Pengaruh Model Discovery Terhadap Pemahaman Konsep IPA dan Sikap Ilmiah Siswa SMP. Program Pascasarjana Universitas Pendidikan Ganesha Program Studi IPA. Singaraja. 